\title{
Reduction process of low-grade nickel laterite agglomerates using different carbonaceous materials
}

\section{Proceso de reducción de aglomerados de lateritas de níquel de bajo grado, usando diferentes materiales carbonosos}

\author{
Sandra Consuelo Díaz-Bello ${ }^{1,2^{*}}$, Oscar Jaime Restrepo-Baena ${ }^{2}$, Álvaro Hernando Forero-Pinilla ${ }^{3}$ \\ ${ }^{1}$ Facultad de Ingeniería Civil, Universidad Santo Tomas. Sede Campus: Av. Universitaria Cll. 48 \# 1-235 Este. C. P. 15003. Tunja, Colombia \\ ${ }^{2}$ Facultad de Minas, Universidad Nacional Colombia. Cra. 65 \# 59a-110. A. A. 3840. Medellín, Colombia \\ ${ }^{3}$ Escuela de Metalurgia, Universidad Pedagógica y Tecnológica Colombia. Av norte Km 1 Vía a Paipa. C. P. 15003. Tunja, Colombia
}

\section{ARTICLE INFO:}

Received November 20, 2017

Accepted August 02, 2018

\section{KEYWORDS:}

Chemical properties, chemical process, nickel minerals, organic compounds, reducing gas

Propiedades químicas, proceso químico, minerales de níquel, compuestos orgánicos, gas redutor
ABSTRACT: Lateritic nickel ores need to be reduced to obtain direct reduced iron and nickel alloy. During processing of lateritic nickel ores in rotary kilns, there is a great loss of fines of ores due to degradation during transport into the reactor. These fines contain substantial amounts of nickel and iron, which could be recovered if they are agglomerated and fed back to the process. It is important to note that the processing of minerals with smaller particle sizes yields more efficient reduction processes because there is more surface area for the reducing agent to react with the mineral particles. This work involves the agglomeration of lateritic ore with a nickel content of $1.78 \%$. Briquettes of $10 \mathrm{~g}$ were manufactured with the addition of various carbonaceous materials, such as coal, molasses, and coke, with a ratio of carbon/oxygen $=1$. These samples were subjected to temperatures of $1100{ }^{\circ} \mathrm{C}$ to reduce the iron and nickel oxides present. The reduction percentages were obtained and the products were analyzed by X-ray diffraction (XRD), atomic absorption, thermogravimetry, and scanning electron microscopy to observe the effectiveness of the reducing agent. The highest reduction percentages (95\%) were obtained when molasses was used as the reducing agent.

RESUMEN: Los minerales de níquel lateríticos necesitan ser reducidos, para obtener hierro directamente reducido y níquel metálico. Durante el procesamiento de minerales lateríticos de níquel en calcinador rotatorio, se evidencia gran pérdida de finos de mineral debido a degradación por transporte dentro del reactor. Estos finos contienen cantidades sustanciales de níquel y de hierro, lo cual podría recuperarse si estos se aglomeran y se alimentan al proceso. Es importante notar que el procesamiento de partículas con tamaños más pequeños, pueden hacer procesos de reducción más eficientes, porque se tiene mayor superficie de área para que el agente reductor reaccione con las partículas de mineral. En este trabajo se llevó a cabo la aglomeración de mineral laterítico con $1.78 \%$ de níquel. Se fabricaron briquetas de $10 \mathrm{~g}$ adicionando diferentes materiales carbonosos, como el carbón, melaza y coque, con una relación de carbono/oxígeno $=1$. Estas muestras se sometieron a temperaturas de $1100^{\circ}$, para reducir los óxidos de hierro y níquel presentes. Los porcentajes de reducción obtenidos y los productos fueron analizados por difracción de rayos $X$, absorción atómica, termo gravimetría (TGA) y microscopía electrónica de barrido, para observar la efectividad del agente reductor. El mejor porcentaje de reducción fue de $95 \%$, cuando la melaza es la utilizada para generar el agente reductor.

\section{Introduction}

Nickel has been obtained from low-grade lateritic ores over the last 100 years, starting with the processing of the mineral garnierite [1]. Given that nickel tenors are decreasing, and that deposits have changed their genesis, laterites have become an important source for the recovery
E-mail: sandra.diazbđausantoto.edu.co

ISSN 0120-6230

e-ISSN 2422-2844 
of this metal. Approximately $40 \%$ of the world production of nickel is extracted from sources of nickel laterites [2]. Such global deposits contribute significantly to the production of nickel, but require considerable capital to cover the complex process of the treatment of laterites [3].

In recent years, there have been increased efforts to reduce emissions of greenhouse gases into the atmosphere; these gases are generated when minerals are processed to produce metals and alloys. Globally, nickel producers are conducting increased researches regarding methods of decreasing environmental pollution [4].

The process of using a rotary kiln-electric furnace (RKEF) is the main technology used globally for the treatment of lateritic nickel ores for the production of ferronickel [5]. In this process, ore fines are generated and emitted into the atmosphere. In addition, the processing of lateritic ores, including reduction, is sometimes followed by hydrometallurgical process for the recovery of nickel, which generates large amounts of environmental pollution [6]. One way to reduce this environmental pollution is by manufacturing agglomerates. These can be processed for the same purpose, reducing the emission of ore fines into the atmosphere. For instance, Japanese producers make briquettes to produce DRI; iron ore and coal are used as reducing agents, and in turn, the coal is used as a binder. This is an option for processing such ores. Tanaka et al, used a ratio of $\mathrm{C} / \mathrm{O}=1$ and reported interesting results for the reduction of iron ore [4]. Limonitic ores are used as source of iron in conventional steelmaking processes that often are restricted by the small particle sizes [7]. When there are problems related to small particle size, agglomerates can be an alternative for processing, regardless of the pyrometallurgical process for which it has been selected.

In China, ferronickel granules are produced from briquettes of nickel laterites, with a certain ratio of mineral/coal at high temperatures. These briquettes were used in direct reduction processes by Dong et al. [8]; they considered variables such as temperature, calcination time, molar ratio of $\mathrm{C} / 0$, and amount of flux to study the quality of the ferronickel obtained. They used $20 \%$ lime as a flux and a ratio of $\mathrm{C} / \mathrm{O}=1.4$. The characterization of the products obtained demonstrated that the iron and nickel are a solid alloy [8].

Another important study is the reduction of ferruginous lateritic ores using self-reducing briquettes. This type of briquette was made from a mixture of minerals with coal as a reducing agent and acting as a binder [9].

Janwong, in 2012, conducted a comprehensive study of the agglomeration of lateritic nickel ores, showing different mechanisms of agglomeration. The study described nickel laterites as containing significant amounts of fine particles and clay minerals, which is often does difficult some hydrometallurgical processes such as heap leaching [10].

Quaicoe et al. developed works on laboratory batch drum agglomeration and continuous column leaching behavior of saprolite (SAP) and goethite (G) Ni laterite ores as part of a quest for an effective ore pre-treatment process for enhanced heap leaching [11]. Agglomeration of fine ore particles to produce robust granules with desirable attributes [12] le.g., size distribution and strength and porosityl is a critically important precursor to the heap leaching process [13].

In 2016, Rao et al. studied the reduction and sulphidation behaviors of a saprolite laterite ore in the presence of sodium sulfate; they conducted thermodynamic analysis, determined the selective reduction and sulphidation ratios, and studied the kinetics [14]. In 2017, Elliott et al. proposed that one method of addressing this issue is to reduce the ore at moderate temperatures to form a ferronickel alloy, which could then be selectively recovered to form a nickel concentrate. The current work explores the effects of varying coal, elemental Sulphur, and pyrite additions on the formation of ferronickel particles from a limonitic ore [15].

In Colombia, ferronickel is obtained from lateritic ores; these minerals are ground to a suitable particle size and processed into one-inch pieces. This study is important because it is based on forming agglomerates of laterites nickeliferous from fine ores. Various reducing agents such as coal, coke, and molasses are used to analyze its behavior when subjected to a reduction process at 1100 ${ }^{\circ} \mathrm{C}$. Agglomeration of such minerals is performed as an alternative to mitigate the generation of ore fines when these are brought to the different extraction processes of nickel and other metals of interest. Furthermore, it is important to take advantage of the properties of each of the reducing agents and to corroborate existing materials, called self-reducers, in the literature.

\section{Materials and methods}

Treated Colombian nickel laterites were analyzed using the techniques of X-ray diffraction, X-ray fluorescence, and scanning electron microscopy (SEM) to identify the mineralogical species. XRF was performed using a team Philips brand FRX 2400. DRX was performed using a team PANalytical and reference $X$ 'pert, with $\mathrm{Cu}$ Source $\mathrm{K}$ Alpha1 and wavelength $=1.5406 \mathrm{~A}$ and a power of $1.8 \mathrm{~kW}$ ( $45 \mathrm{kV}$ - $40 \mathrm{~mA}$ ), and (field emission scanning electron microscopy (FESEM) with a Jeol 6701 EDXS 
Table 1 Chemical composition of Colombian lateritic ore

\begin{tabular}{cccccc}
\hline$\% \mathrm{NiO}(\mathbf{s})$ & $\mathrm{\% Fe}_{\mathbf{2}} \mathbf{O}_{3}(\mathbf{s})$ & $\% \mathrm{MgO}(\mathbf{s})$ & $\mathbf{\% S i O}_{\mathbf{2}}(\mathbf{s})$ & $\mathbf{A l}_{\mathbf{2}_{\mathbf{3}}}(\mathbf{s})$ & $\mathbf{H}_{\mathbf{2}} \mathbf{O}$ \\
\hline 2.27 & 19.7 & 21.3 & 40.5 & 1.9 & 14.3 \\
\hline
\end{tabular}

probe. Thermal gravimetric analysis (TGA) was performed using a team TA Instruments, 1600 . The ore was heated to $1000{ }^{\circ} \mathrm{C}$ to determine the changes that occurred when the temperature was increased.

The agglomeration process was performed with a hydraulic press, mark Enerpac, with a maximum capacity of 10,000 psi (70 MPa). The carbonic materials used were molasses, coal, and coke. Additional tests were conducted on a piece of ore, and coke and molasses mixture.

Colombian nickel laterites were pulverized through a size 100 mesh (150 microns), mixed with reducing agents, and then compacted in a hydraulic press at a force of $25 \mathrm{MPa}$. The briquettes were manufactured to have a mass of $10 \mathrm{~g}$ and a diameter and height of 1 inch. The briquettes were subjected to reduction processes at 1100 ${ }^{\circ} \mathrm{C}$, with a residence time of three hours. The proportion of binder was established as the ratio of carbon/oxygen. This ratio refers to the oxygen present in the sample of iron oxide and nickel oxide, calculated stoichiometrically. The ratio was determined as $\mathrm{C} / \mathrm{O}=1$ by the corresponding thermodynamic analysis for this type of mineral.

\section{Results and discussion}

\subsection{Chemical composition of low-grade nickel ore}

The sample was analyzed using the technique of X-ray fluorescence as shown in Table 1. Figure 1 shows the $X$-ray diffractogram, which indicates the presence of lizardite $\left(\mathrm{H}_{4} \mathrm{Mg}_{3} \mathrm{O}_{9} \mathrm{Si}_{2}\right)$, Nepouite $\left(\mathrm{Ni}_{3} \mathrm{Si}_{2} \mathrm{O}_{5}(\mathrm{OH})_{4}\right)$, iron as Goethite $\left(\mathrm{Fe}_{2} \mathrm{O}_{3} \cdot \mathrm{H} \mathrm{H}_{2} \mathrm{O}\right)$, and quartz $\left(\mathrm{SiO}_{2}\right)$.

This indicates that the ores used are silicates. These ores can be decomposed by chemical processes such as pyrometallurgy, because these ores have very strong bonds that do not facilitate easy separation of the metal of interest.

The SEM analysis shows that nickel is associated with silicon in form of silicates, as shown in the diffractogram in Figure 1. Figure 2 shows the SEM mapping.

The SEM images show that nickel is distributed throughout sample. This information corroborates the DRX results, and it is concluded that nickel ores must be treated by pyrometallurgical processes such as calcination and reduction to obtain the metal (FeNi).

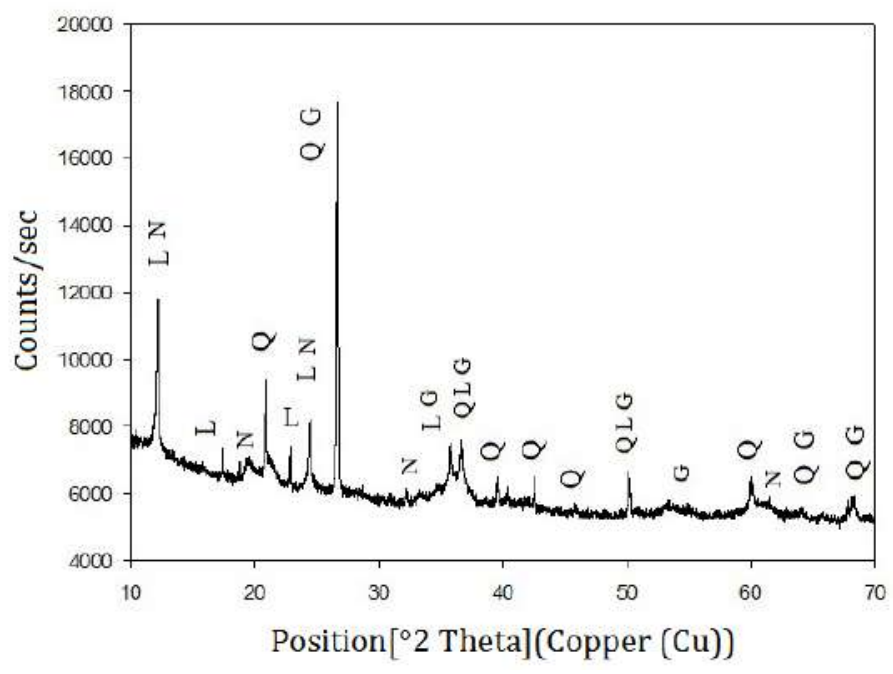

Figure $1 \mathrm{X}$-ray diffractogram of lateritic ore, L: Lizardite, N: Nepouite, Q: Quartz, G: Goethite

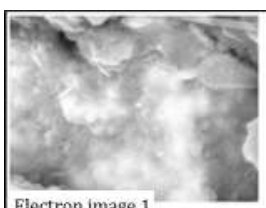

Electron image 1
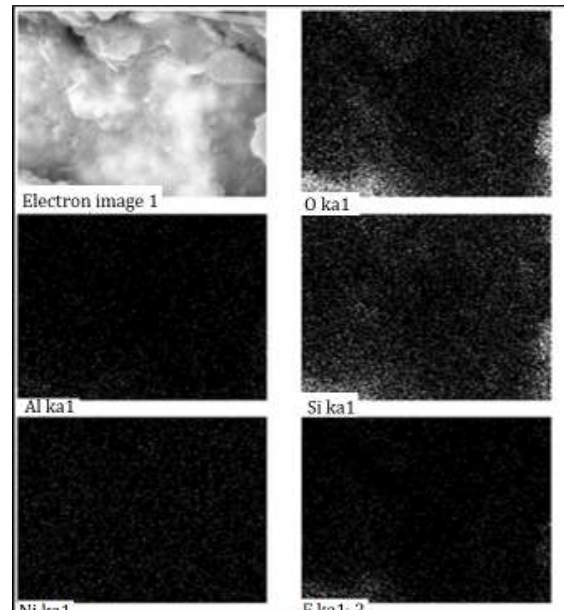

oka1
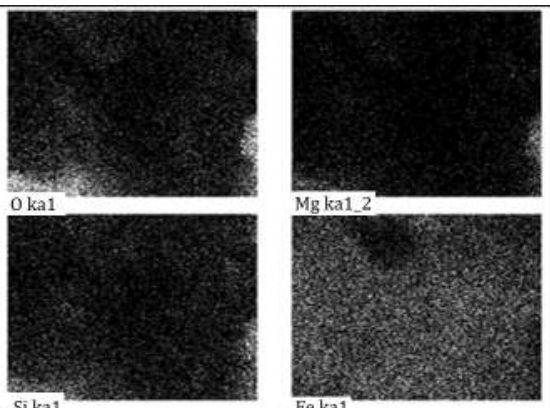

Mgka1_2
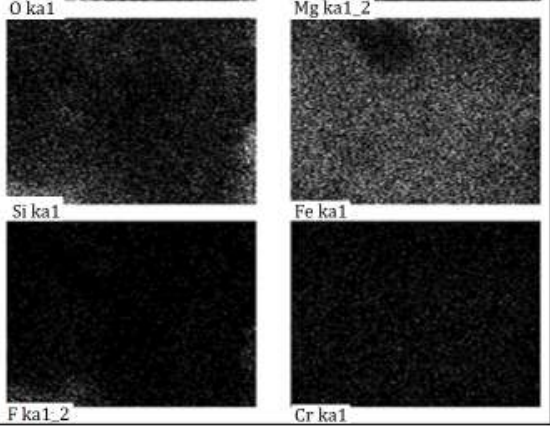

Crka1

Figure 2 Mapping by scanning electron microscopy for a sample of lateritic ore

\subsection{Reducing agents and reduction process}

As an alternative, in the reduction of nickel ores, different carbonaceous material reducing agents were used simultaneously to agglomerate the ore particles; this was done to take advantage of the adhesion properties of these materials. Molasses, coal, and coke were mixed with lateritic nickel ore and then subjected to reduction processes at $1100^{\circ} \mathrm{C}$. The reduction process results of the reducing agents are shown in Figure 3.

The results in Figure 3 were obtained by atomic absorption to determine the amount of iron present in the final products. It is very important to take into account that for treating nickel ore in pieces, the iron reduction was $46 \%$, indicating that the fine material has a higher surface 


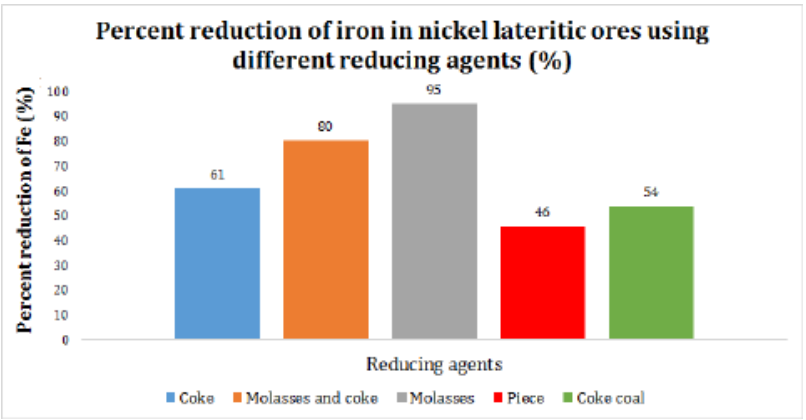

Figure 3 Percentage reduction of iron in lateritic nickel ores using different reducing agents $(\%)$

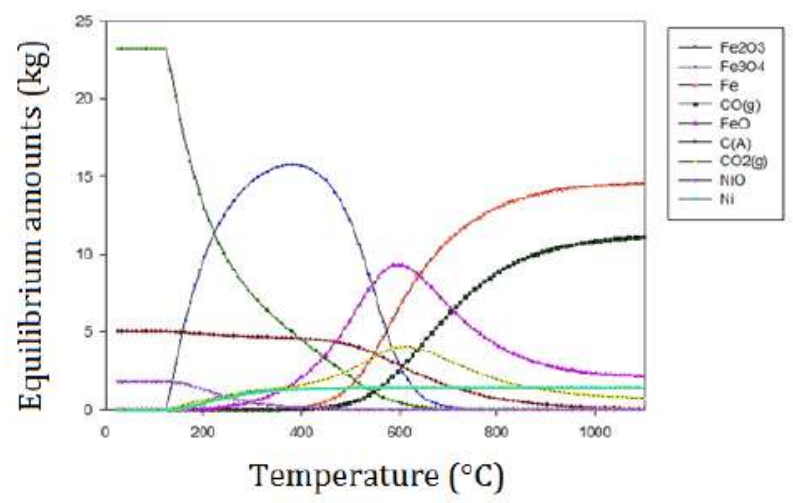

Figure 4 Equilibrium compositions diagram of the oxidized species present in a laterite, favoring the formation of $\mathrm{CO}(\mathrm{g})$ above $1000^{\circ} \mathrm{C}[16]$

area and the reducing agent passes more easily through the particulates, eliminating a great amount of the oxygen present. It should be noted that the nickel ores reduced with coke coal did not show a favorable reduction percentage (54\%). As an alternative, molasses was used as a reducing agent to improve the agglomeration process. Molasses is used for its ability to bind fine particles and because it is an organic material that decomposes at 186 ${ }^{\circ} \mathrm{C}$ into $\mathrm{CO} 2$ and water vapor, as shown in Equation 1.

$\mathrm{C}_{12} \mathrm{H}_{22} \mathrm{O}_{11}+12 \mathrm{O}_{2}(\mathrm{~g}) \rightarrow 12 \mathrm{CO}_{2}(\mathrm{~g})+11 \mathrm{H}_{2} \mathrm{O}(\mathrm{g})$

Reaction (1) is favorable for the process since the produced $\mathrm{CO} 2 \mathrm{lg})$ when mixed with excess carbon results in the Boudouard reaction, as shown in Equation 2

$$
\mathrm{C}+\mathrm{CO}_{2}(g) \rightarrow 2 \mathrm{CO}(g), \Delta G_{700^{\circ} \mathrm{C}}=-0.015 \mathrm{KJ}
$$

In direct reduction processes of iron ore and nickel, the Boudouard reaction is important because the gaseous reducing agent that is formed is $\mathrm{CO}(\mathrm{g})$. This can be seen in Figure 4, in which the formation of $\mathrm{CO}(\mathrm{g})$ and its stability is shown to occur above $1000^{\circ} \mathrm{C}$.

The formation of $\mathrm{CO}(\mathrm{g})$ as the reducing agent is favored at a temperature of $700{ }^{\circ} \mathrm{C}$ with $\Delta \mathrm{G} 700^{\circ} \mathrm{C}=-0.015 \mathrm{KJ}$, as

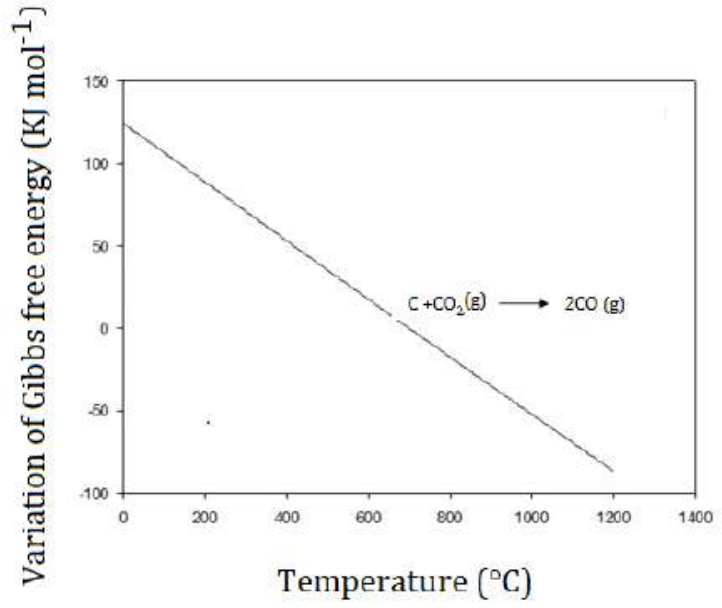

Figure 5 Boudouard reaction

seen in Figure 5. In this figure, it is evident that there is a variation in the Gibbs free energy as the temperature rises. This variation shows that the higher the temperature, the greater the chance of stabilizing $\mathrm{CO}(\mathrm{g})$.

\subsection{Characterization of agglomerates and reduction products}

The products of the reducing process of the mineral treated with different reducing agents were characterized using XRD. The species found after the process were lizardite $\left(\mathrm{Mg}_{3} \mathrm{Si}_{2} \mathrm{O}_{5}(\mathrm{OH})_{4}\right)$, forsterite $\left(\mathrm{Mg}_{2} \mathrm{SiO}_{4}\right)$, fayalite $\left(\left(\mathrm{Fe}_{2}+\right) 2 \mathrm{SiO}_{4}\right)$, quartz $\left(\mathrm{SiO}_{2}\right)$, magnetite $\left(\mathrm{Fe}_{3} \mathrm{O}_{4}\right)$, and $\mathrm{Fe}$ and $\mathrm{Ni}$ metal (FeNi), as shown in Figure 6.

In addition, briquettes with different reducing agents were analyzed using SEM before and after the reduction process to determine the effect of each binder. Figure 7 shows the mineral particles bonded with molasses, coke coal, and coke, before being subjected to the reduction process.

In Figure 7, the three reducing agents are observed. Figure 7 a shows the ore particles with molasses, and the formation of lateritic ore agglomerates is clear. Figure 7 b) shows the coal agglomerates; it should be noted that coke coal has plastic properties at temperatures of $450^{\circ} \mathrm{C}$, and can therefore be used as a binder to take advantages of its properties. Figure $7 \mathrm{c}$ ) shows the agglomerated ore with coke, where the particles are not agglomerated but flatten when pressure is applied. This means that the coke briquettes are not very resistant to transport in reactors such as rotary kilns, and cause degradation of the fed material. Figure 8 shows the microscopy of the briquettes when they are reduced at $1100^{\circ} \mathrm{C}$. 

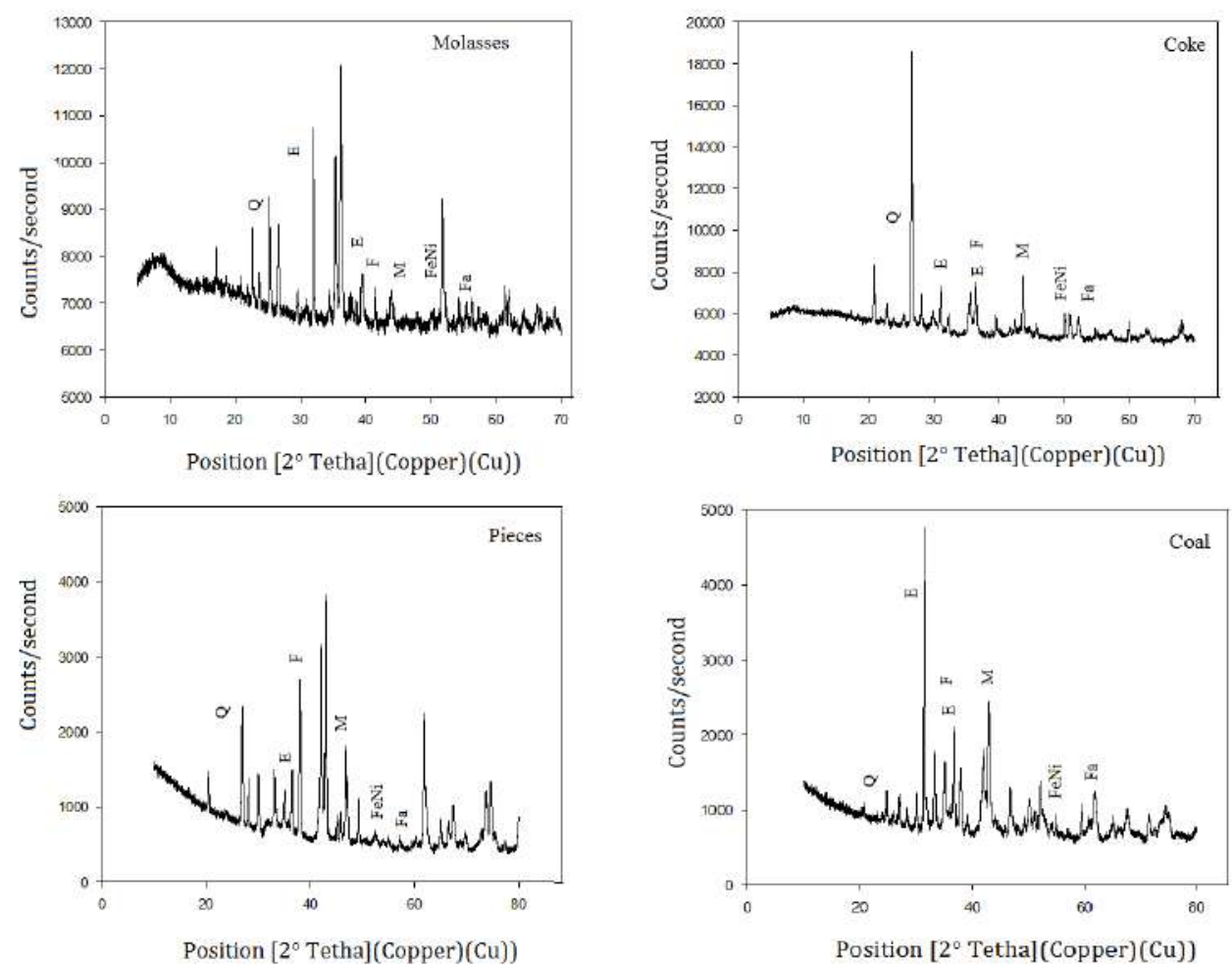

Figure 6 X-ray diffractograms of the samples with different reducing agents. Q: quartz, E: enstatite, F: forsterite, M: Magnetite, FeNi: ferronickel, Fa: fayalite
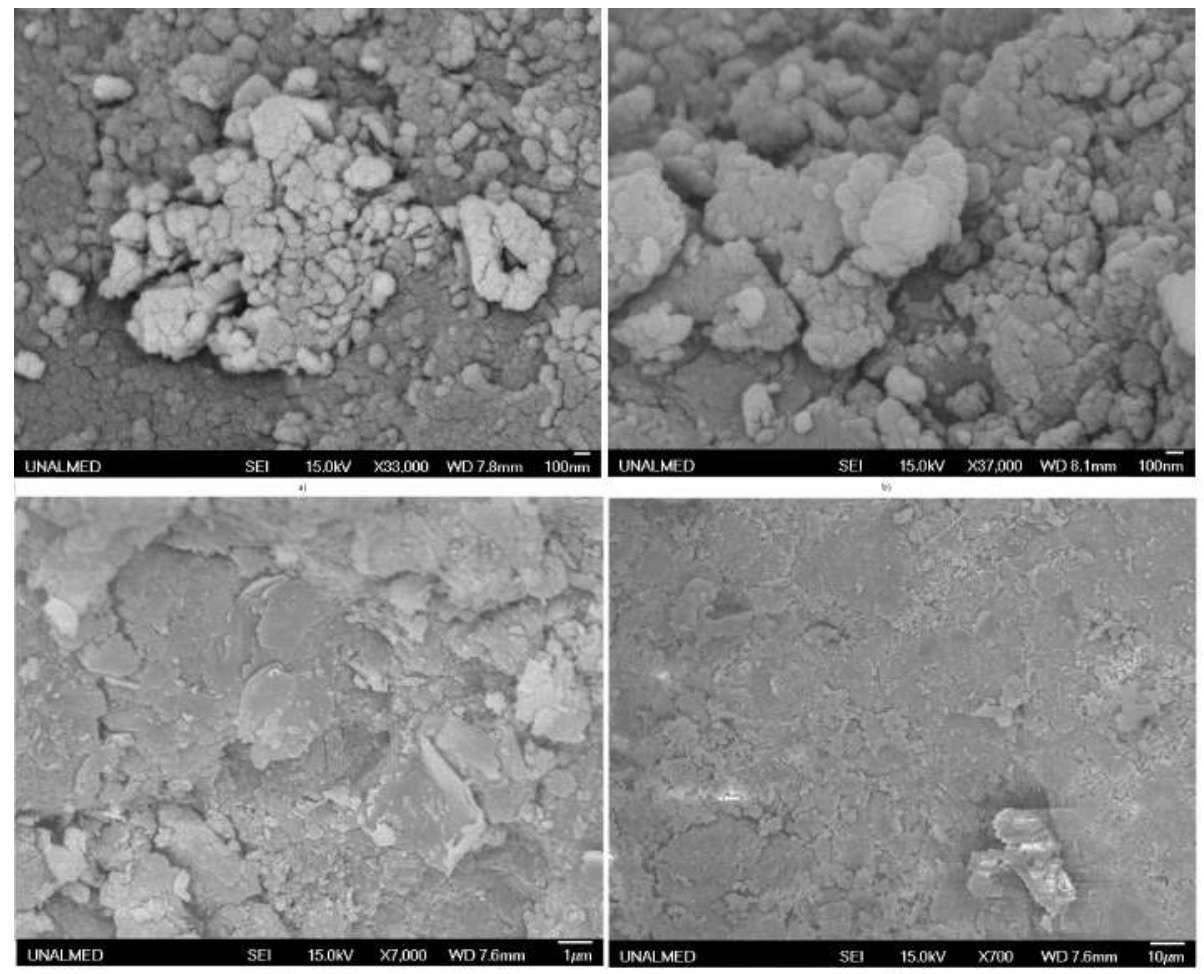

Figure 7 Scanning electron microscopy for briquettes obtained using different reducing agents. a) molasses, b) coke coal, c) and d) 

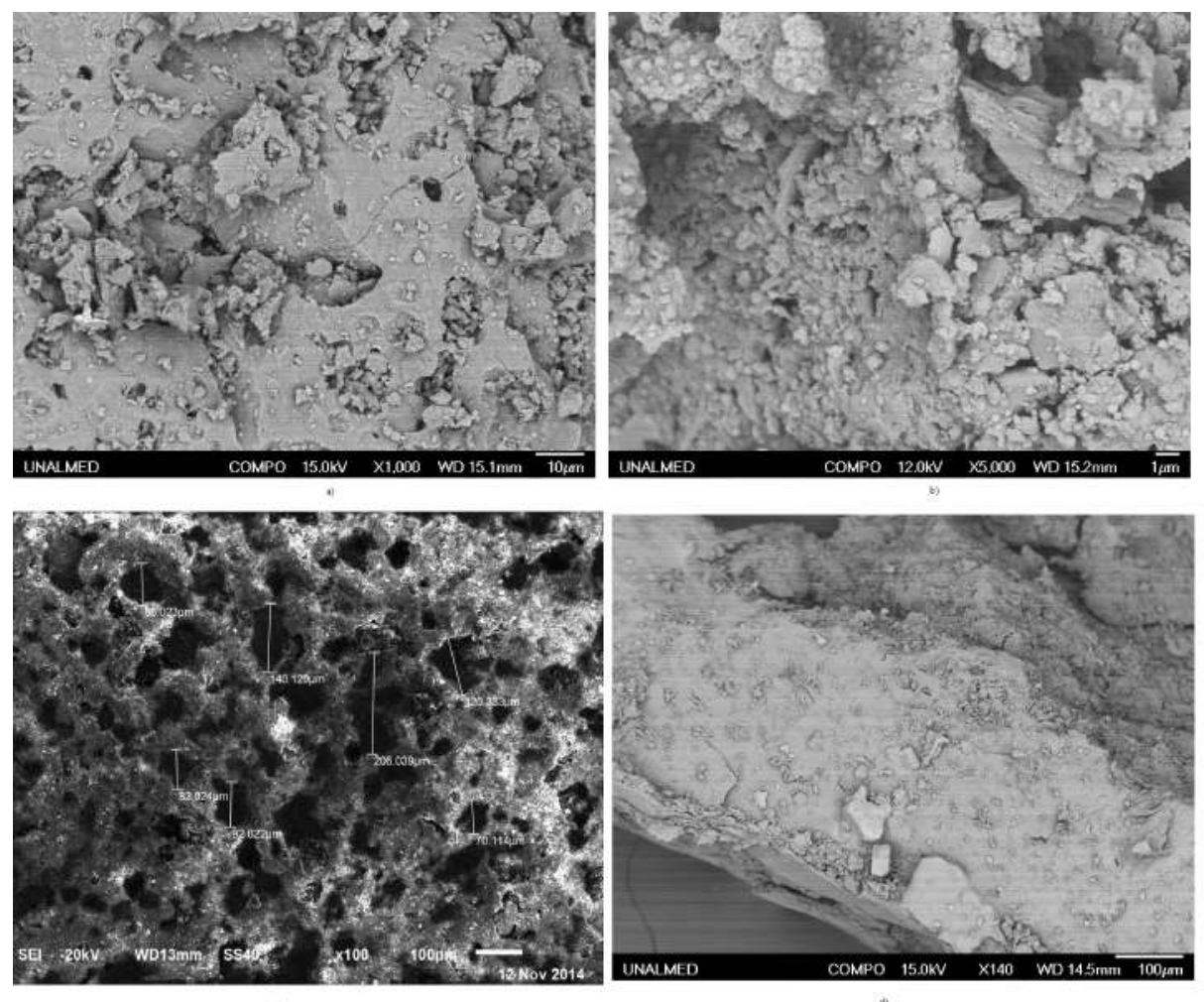

Figure 8 Scanning electron microscopy for briquettes obtained using different reducing agents after the reduction process; al Molasses, b) coke, cl and d) coke coal, d) piece with no agent

Figure 8 a) shows pre-reduced lateritic nickel ore with molasses as the reducing agent.

The atomic absorption results show that this is one of the reducing agents with better reduction results of, and it can be concluded that molasse, in addition to having good binding properties, is an excellent reducing agent; slight porosity is clear in the figure. Figure 8 b) shows a reduced coke briquette, in which the mineral particles are not sufficiently porous, meaning that the reducing gas did not have the same effect as with the molasses. Figure 8 c) shows the reduction of the ore sample reduced using coke coal; is observed to be porous, indicating that the reducing agent was in contact with the agglomerates, although the results of atomic absorption show that the percentage reduction is not sufficient to ensure that this is a good reducing agent. Figure $8 \mathrm{~d}$ ) shows a piece of ore that was reduced under the same conditions, but without a reducing agent passing through the sample; it obtained a reduction of $46 \%$.

The TGA results show that the ore changes with increasing temperature. Coke, coal, and molasses mixed with ore lose mass as the temperature increases. The mix with ore and coke is subject to an $18 \%$ loss in weight, as shown in Figure 9. In the figure, part al shows a transformation at $200^{\circ} \mathrm{C}$, which in this case is the transformation of goethite; part b) shows the transformation of iron oxides (magnetite and wustite), and part c) shows the formation of iron and nickel alloy.

The coal sample shows a $14 \%$ loss in weight (Figure 10). In addition, there are not many changes in this sample.

Figure 11 shows that the molasses sample undergoes various changes and a $22 \%$ loss in weight. Part a) indicates that transformation of goethite, which initiates above 86 ${ }^{\circ} \mathrm{C}$; part b) shows the transformation of the iron oxides; and part c) shows the formation of nickel and iron alloy metallic. This analysis corroborates the equilibrium compositions diagram obtained in the thermodynamic analysis and confirms that molasses is a good reducing agent.

The information obtained by TGA shows that the molasses can be used as a reducing agent. This material generates good reduction results.

It is very important because the amount of iron and nickel alloy obtained is higher. 


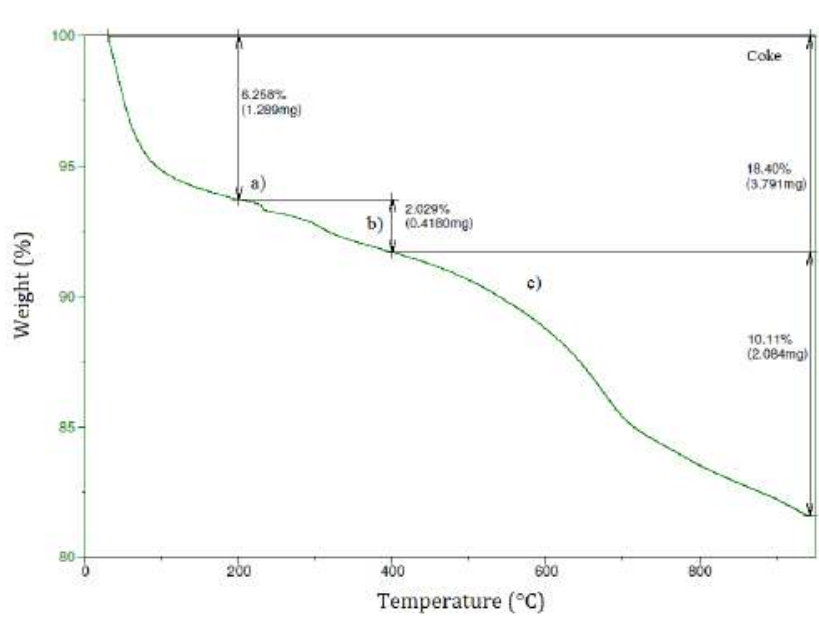

Figure 9 TGA of the sample ore mixed with coke

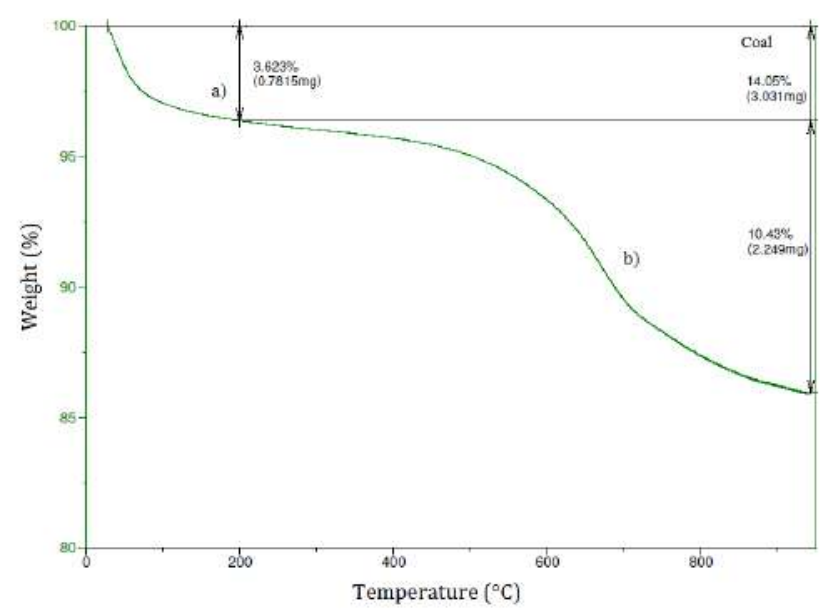

Figure 10 TGA of the sample ore mixed with coal

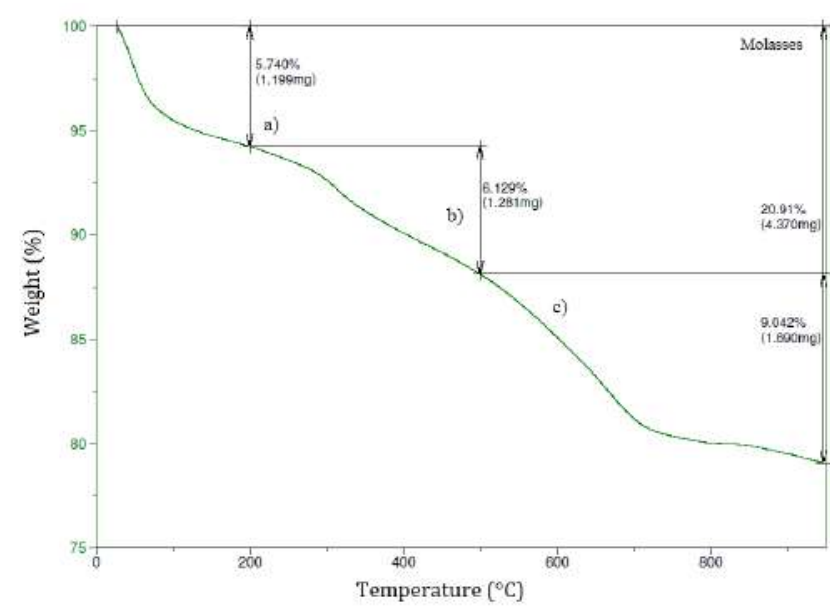

Figure 11 TGA of the sample ore mixed with coal

The reduction percentage data obtained shows good results for the use of carbonaceous materials as reducing agents. Molasses is a carbonaceous material that is economical and easy to obtain, and is very attractive in this type of process for its high efficiency and capability as a binder.

The calcination and reduction processes must be efficient to obtain a significant amount of metal ( $\mathrm{FeNi})$ in the final process under excellent conditions.

\section{Conclusions}

It can be concluded from the X-ray diffraction and atomic absorption results that molasses is an organic material that can be used as a reducing agent, based on the decomposition reaction that occurs when subjected to high temperatures. In addition, it has properties as a binder. As a binder, coal has good properties of plasticity which helps the particles to agglomerate more easily. Coal as a reducing agent has a reduction of $54 \%$, which is not favorable for this type of processes. Coke is not a good binder, but should not be discounted as a reducing agent; it showed a reduction rate of $60 \%$, considering that is reactive at high temperatures. If used in excess, it can function as a good solid reducing agent and can be a good alternative in the process of reducing this type of lateritic nickel ore.

The agglomeration process is a good alternative to work lateritic nickel ores, considering that reduction is more effective when fine particles are reduced through a diffusion process whereby the reducing agent passes through the particles ore. This is evidenced, when the percentages of reduction, of pieces of mineral reduced to the same conditions of work, are compared with the agglomerates. Agglomeration is a way to mitigate the generation of fine particles in the processing of lateritic nickel ores. It can be used as an alternative for the recovery of elements such as iron and nickel present in such minerals, when these are transported.

\section{References}

[1] A. D. Dalvi, W. G. Bacon, and R. C. Osborne, "The past and the future of nickel laterites," in PDAC 2004 International Convention, Trade Show \& Investors Exchange, Ontario, Canada, 2004, pp. 1-27.

[2] G. Li, T. Shi, M. Rao, T. Jiang, and Y. Zhang, "Beneficiation of nickeliferous laterite by reduction roasting in the presence of sodium sulfate," Miner. Eng., vol. 32, pp. 19-26, May 2012.

[3] U. de Planeacion Minero energética UPME, Niquel en Colombia. Bogotá, Colombia: UPME, 2009.

[4] Y. Tanaka, T. Ueno, K. Okumura, and S. Hayashi, "Reaction behavior of coal rich composite iron ore hot briquettes under load at high temperatures until $1400^{\circ} \mathrm{C}$," ISIJ Int., vol. 51, no. 8, pp. 1240-1246, 2011.

[5] M. Liu, X. Lv, E. Guo, P. Chen, and Q. Yuan, "Novel process of ferronickel nugget production from nickel laterite by semi-molten state reduction," ISIJ Int., vol. 54, no. 8, pp. 1749-1754, 2014. 
[6] Z. Yu., M. Wen, L. Yan, and X. Qian, “A green process for recovering nickel from nickeliferous laterite ores," Trans. Nonferrous Met. Soc. China, vol. 20, no. 1, pp. s65-s70, May 2010.

[7] P. Ji, K. Hyun, and J. Sung, "Use of oxidation roasting to control nio reduction in ni-bearing limonitic laterite," Minerals Engineering, vol. 71, pp. 205-215, Feb 2015.

[8] D. H. Huang, J. L. Zhang, C. C. Lin, and R. Mao, "Production of ferro-nickel granules from nickel laterite ore/coal composite briquettes by direct reduction," Beijing Keji Daxue Xuebao/Journal Univ. Sci. Technol. Beijing, vol. 33, no. 12, pp. 1442-1447, Dec 2011.

[9] F. Peñaloza and D. Speciale-Fay, "Obtención de dri a partir de briquetas autoreductoras de concentrado de mineral de laterita ferruginosa," B.Sc thesis, Universidad Central de Venezuela, Caracas, Venezuela, 2004.

[10] A. Janwong, "The agglomeration of nickel laterite ore," Ph.D. dissertation, University of Utah, Logan, Utah, United States., 2012.

[11] I. Quaicoe, A. Nosrati, W. Skinner, and J. Addai, "Agglomeration and column leaching behaviour of goethitic and saprolitic nickel laterite ores," Minerals Engineering, vol. 65, pp. 1-8, Oct 2014.
[12] I. Quaicoe, A. Nosrati, W. Skinner, and Addai, "Agglomeration behaviour and product structure of clay and oxide minerals," Chem. Eng. Sci., vol. 98, pp. 40-50, Jul 2013.

[13] A. Nosrati, J. Addai, and D. J. Robinson, "Drum agglomeration behavior of nickel laterite ore: Effect of process variables," Hydrometallurgy, vol. 125-126, pp. 90-99, Aug 2012.

[14] M. R. et al, "Reductive roasting of nickel laterite ore with sodium sulfate for fe-ni production. part i: Reduction/sulphidation characteristics," Sep. Sci. Technol., vol. 51, no. 8, pp. 1408-1420, Mar 2016.

[15] R. Elliott, C. A. Pickles, and J. Peacey, "erronickel particle formation during the carbothermic reduction of a limonitic laterite ore," Miner. Eng., vol. 100, pp. 166-176, Jan 2017.

[16] S. C. Díaz, A. Garcés, 0. J. Restrepo, M. A. Lara, and J. E. Camporredondo, "Thermodynamic analysis of the reduction process of colombian lateritic nickel ore," Rev. Metal., vol. 51, pp. 1-8, Dec 2015 